\title{
Constrained Individualism in Group Litigation: Requiring Class Members to Make a Good Cause Showing Before Opting Out of a Federal Class
} Action

\author{
Mark W. Friedman
}

Conventional wisdom instructs that class actions, which vest control of litigation involving many class members in the hands of a few class representatives, interfere with the exercise of an individual's right to direct her own lawsuit. Class action proponents and opponents alike accept this dogma when they assume that the only defense of group litigation is that its varied benefits outweigh the harms attendant to a loss of individual control over litigation. ${ }^{1}$ In contrast, this Note argues that the traditional characterization of individualism is inappropriate in the class action context. The important individual interests implicated by group litigation recommend a revision of Rule 23's "opt out" provision so as to make it available to all class members contingent upon a good cause showing. ${ }^{2}$

1. Two examples relying on very different assessments of class action benefits are the majority opinion in Phillips Petroleum v. Shutts, 472 U.S. 797, 808 (1985) (class action "was an invention of equity" allowing "suits where the number of those interested in the litigation was too great to permit joinder"), and Justice Douglas" observation that "a class action serves not only the convenience of the parties but also prompt, efficient judicial administration. I think in our society that is growing in complexity there are bound to be innumerable people in common disasters, calamities, or ventures who would go begging for justice without the class action but who could with all regard to due process be protected by it." Eisen v. Carlisle \& Jacquelin, 417 U.S. 156, 185 (1974) (Douglas, J., dissenting in part) (footnote omitted) (emphasis added).

2. Rule $\mathbf{2 3}$ of the Federal Rules of Civil Procedure authorizes and describes class action suits. Rule 23(a) establishes four prerequisites to maintaining a class action: that the number of people in the class be too numerous to permit ordinary joinder, that members of the class share common questions of law or fact; that the "claims or defenses of the representative parties are typical of the claims or defenses of the class"; and that "the representative parties will fairly and adequately protect the interests of the class." FED. R. Crv. P. 23(a). Once the demands of section (a) are satisfied, the party requesting class certification must demonstrate compliance with one of the three subdivisions found in section (b). Eisen, 417 U.S. at 163. Litigants may maintain suits under sections $b(1)$ and $b(2)$ where separate actions might result in judgments subjecting the party opposing the class to inconsistent standards of conduct, resulting either from conflicting injunctions or from an inability to satisfy all claimants when money damages are at issue. See Amendments to Rules of Civil Procedure, 39 F.R.D. 69, 100-02 (1966) (Advisory Committee's Notes). In contrast, subdivision $\mathrm{b}(3)$ is available where group litigation predominantly seeking money damages would be "convenient and desirable" and where questions "common to the class predominate over the questions affecting individual members." Id. at 102-03. Primarily, however, this Note is concerned with the provision, unique to suits brought under subdivision $b(3)$, which instructs: 
Any abstract argument about "individual interests" is worthy of exposition not for its own sake, but because it could have real consequences for real litigants. After all, the fundamentally important interests at stake in any litigation are defined by the substance of the dispute-egregious deprivation of civil rights at the hand of the state, frustrated expectations owing to a broken contract, financial tragedy wreaked by an unfaithful fiduciary, grievous and painful bodily injury inflicted by an unsafe product. Nevertheless, implicit in this Note is a belief that debates over the nature of individualism are not merely academic, for those debates produce rules that regulate the opportunities for redress available within our legal system. Theory and doctrine are of little immediate comfort to an ailing victim, but by defining who is entitled, and how people are entitled, to seek legal redress for injury, they work a certain magic: they turn victims into plaintiffs.

While this Note engages the class action primarily in theoretical terms, it also endeavors to discover practical deficiencies in Federal Rule of Civil Procedure 23's opt out provision. Accordingly, Part I of this Note identifies two possible characterizations of individualism and (the lack of) constitutional guidance in choosing to valorize one over the other. Looking more to how the class device functions in practice, Part II focuses primarily on two of the actors involved in any class suit in order to determine whose conception of individualism deserves priority. Part III reformulates Rule 23's opt out provision and measures the reformed rule against our aspirations regarding class litigation.

\section{WHAT INDIVIDUALISM?}

Meaningful discussion about the character of individualism can only proceed from a clear understanding of what one means when one invokes the term. At first glance, opting out of a suit controlled by others seems to be a paradigmatic example of individualism from which one could derive a convincing definition. Rule 23(c)(2) seems to allow an individual litigant, in the name of individualism, to say to the class representative, "Litigate your interests, not mine." 3 That definition becomes less convincing, however, if other litigants can make competing claims sounding in the language of individualism, claims based on

(A) the court will exclude the member from the class if the member so requests by a specified date; (B) the judgment, whether favorable or not, will include all members who do not request exclusion; and (C) any member who does not request exclusion may, if the member desires, enter an appearance through counsel.

FED. R. CIV. P. 23(c)(2). Those who do not elect to leave the suit will find that the doctrine of res judicata binds them to the judgment concerning the class, be it favorable or unfavorable, just as if they had been parties to any individual action. $18 \mathrm{C}$. WRTGHT, A. MILLER \& E. COOPER, FEDERAL PRACTICE AND PROCEDURE § 4455, at 471-73 (1981); see also Hansberry v. Lee, 311 U.S. 32, 40-43 (1940).

3. See Vas-Cath Inc. v. Mahurkar, No. 88-4997, 1990 WL 125702, 35-37 (N.D. Ill.) ("IT]he idea that someone may be bound by the results of a case even though he did not participate is in tension with the autonomy recognized by our legal system ... [but] [c]lass actions do not offend accepted [autonomy] principles in the same way" because class members can opt out.). 
their need for an effective mechanism by which to vindicate their rights. The task, then, is to sort out the various individualist concerns that necessarily come into play when various litigants simultaneously seek to go to court. More specifically, how well does the vision of individual control of suits, which is embodied in opting out, match up with litigation controlled by groups?

In fact, both the statutory arrangement that allows unregulated opting out and the theory behind it appear to be flatly inconsistent with the innovation of group litigation, namely that similarity of interest among class members allows one individual to represent another when litigating over common interests. ${ }^{4}$ This apparent inconsistency in the Federal Rules reflects a certain ambivalence about allowing, in every class suit, representation of an individual by a class without that individual's consent. Thus, Rule 23(c)(2) makes opting out available only to members of classes certified under Rule 23(b)(3), classes which the Rules assume to be less cohesive than those certified under either Rule 23(b)(1) or (b)(2) in that they include some class members whose interests diverge from those held by the class representatives. ${ }^{5}$

Proceeding from this assumption, the Federal Rules of Civil Procedure do not test for similarity or difference of interest on a case-by-case basis. Rather, the Rules treat the $b(1) / b(2) / b(3)$ classification scheme as a proxy for making judgments about cohesiveness, categorically concluding that $b(3)$ classes are generally less cohesive than $b(1)$ or $b(2)$ classes. Because the $b(3)$ class is ostensibly less cohesive, individual litigants are permitted to pursue their divergent claims by exiting the class suit.

Of course, if the interests of the opter out and the class representative were fundamentally different, resolution of the class suit would not interfere with the ability of an individual litigant independently to vindicate her claim; the class and the individual suits simply would not speak to one another. Consequently, the Rules actually protect a weaker and more ambiguous admonition than that previously identified, namely, "Litigate your interests, not mine, although our interests overlap in part." Insofar as b(3) classes are concerned, the Federal

4. Compare the holding in Mullane v. Central Hanover Bank \& Trust, 339 U.S. 306, 313 (1950), that "the individual interest ... is identical with that of the class" with the Advisory Committee's comment on Rule 23(c)(2): "[T]he interests of the individuals in pursuing their own litigations may be so strong here as to warrant denial of a class action altogether. Even when a class action is maintained under subdivision (b)(3), this individual interest is respected." Amendments to the Rules of Civil Procedure, supra note 2, at 104-05 (emphasis added). See also Dubin v. Miller, No. 85-2184, 1990 WL 126266, 35 (D. Colo.) ("rationale behind the requirement that the class representative's claims be typical of the class claims is recognition that a plaintiff with claims typical of the class will, in pursuing and defending his own self interest in the litigation, be concomitantly advancing or defending the interests of the class").

5. Kaplan, Continuing Work of the Civil Committee: 1966 Amendments to the Federal Rules of Civil Procedure (I), 81 HARV. L. REV. 356, 390 (1967); see also Walsh v. Great Atlantic \& Pacific Tea Co., 726 F.2d 956, 963 (3d Cir. 1983) ((b)(3) classes less cohesive than those certified under b(1) or b(2)); Holmes v. Continental Can Co., 706 F.2d 1144, 1156 (11th Cir. 1983) (same); Barefield v. Chevron, U.S.A., Inc., 12 Fed R. Serv. 3d 1232, 1237-39 (N.D. Cal. 1988) (Unlike b(3) actions, the "trademark of the b(2) action is homogeneity. It is this characteristic that allows the court to . . . bind all members to any judgment on the merits without an opportunity to opt out."). 
Rules allow identifiable differences in interest to trump identifiable similarities. This systematic, categorical presumption in favor of differences reflects the traditional litany encouraging group litigation only as long as it does not intrude on an individual's ability to vindicate her rights in court. If, however, opting out impedes the ability of class members to vindicate their rights, then on what basis can we justify this systematic presumption in favor of opting out? Why does the individual's interest have priority?

Such prioritization turns on nothing more and, importantly, nothing less than the "deep-rooted historic tradition that everyone should have his [sic] own day in court." But this bedrock principle admits of two interpretations: that "everyone should have his own day in court," or that "everyone should have his own day in court." The very availability of class actions is an expression of the former interpretation. Such a conception might be termed the equal access principle, as it ensures that legally unsophisticated people are not denied a day in court. Attaining equal access, however, requires that sometimes the desires or interests of individual class members be constrained in favor of collective interests. In contrast, the particular opt out provision currently ensconced in Rule 23 valorizes what might be characterized as the open access principle insofar as it embraces unconstrained individualism. This provision, which permits each and every putative class member to control his own suit, for any reason, or for no reason at all, promotes society's desire that everyone should have "his own" day in court.

Recognition of the fact that we may select between two characterizations of individualism does not, however, provide guidance as to how to select one over the other. Unfortunately, neither the Constitution nor the Supreme Court lend much assistance. One might expect the Supreme Court, particularly the current Supreme Court, to adopt the open access principle without reservation. ${ }^{7}$ Surprisingly, however, the Court has recently hesitated in its embrace of unconstrained individualism. In Phillips Petroleum v. Shutts, ${ }^{8}$ the Court held that "due process requires at a minimum that an absent plaintiff be provided with an opportunity to remove himself from the class by executing and returning an 'opt out' or 'request for exclusion' form." While Shutts might be read as affirming the ideal of unconstrained individualism, such an interpretation would be superficial.

A more nuanced reading of Shutts reveals three ways in which the Court rejected unconstrained individualism. First, the Court did not labor over its summary conclusion, leaving unclear the scope of the right to excuse oneself

6. Martin v. Wilks, 109 S. Ct. 2180, 2184 (1989) (quoting 18 C. WRIGHT, A. MILLER \& E. COOPER, FEDERAL PRACTICE AND PROCEDURE § 4449, at 417 (1981)).

7. Cf. Martin v. Wilks, $109 \mathrm{~S}$. Ct. at 2180 (holding that, in the absence of privity, consent decree did not bind those who were not parties when the consent decree was negotiated and agreed to).

8. 472 U.S. 797 (1985).

9. Id. at 812 . 
from a class. This failing is particularly significant when viewed against a statutory and doctrinal background that also fails to define the right with any precision. For example, Rule 23 by its own terms fails to specify the method of exclusion. ${ }^{10}$ Indeed, the constitutional and philosophical underpinnings of the right to opt out are so ambiguous that before Shutts lower courts divided over whether any such constitutional right even existed. ${ }^{11}$

Second, in Shutts, the Court explicitly rejected the argument that due process required putative class members to assent affirmatively to a class suit by "opting in,"12 the method by which class joinder had been accomplished prior to the 1966 revision of the Federal Rules. ${ }^{13}$ Clearly, an opt in rule resonates more strongly with the principle of unconstrained individualism than does even a liberal opt out rule, because under an opt in rule, no potential class member may be bound to the results of a class suit until she actually joins the class. One might argue that the Court's reluctance to return to the pre-1966 opt in regime is attributable to the Court's desire to respect the explicit language and purposes of the 1966 rule reform. The simple reply to this argument is that Rule 23 is, at best, a statute, ${ }^{14}$ whereas Shutts was in relevant part a decision explicitly based on constitutional due process. Reading the Constitution in light of a statute would, of course, imply inversion of our constitutional system.

The third piece of evidence demonstrating that Shutts did not affirm unconstrained individualism is that the Court explicitly left intact ${ }^{15}$ the Federal Rules' failure to provide for any mandatory opt out right in actions maintained under subdivisions $b(1)$ or $b(2) .{ }^{16}$ Class plaintiffs in these suits have no opportunity to assert individual claims as a matter of right, suggesting that the Court recognized instances in which unconstrained individualism would not allow unconditional exit from a class suit. Of course, the Court's refusal to consider whether the same right to opt out afforded $b(3)$ class members should also be available to $b(1)$ and $b(2)$ class members might reasonably be ascribed to the

10. FED. R. CTV. P. 23(c)(2).

11. Compare Kincade v. General Tire \& Rubber Co., 635 F.2d 501, 506 (5th Cir. 1981) (opportunity to opt out is statutory, not constitutional) and Robertson v. National Basketball Ass'n, 556 F.2d 682, 685-86 (2d Cir. 1977) (denial of opportunity to opt out does not violate constitutional due process) with DeGier v. McDonald's Corp., 76 F.R.D. 125, 127 (N.D. Cal. 1977) (right to opt out of b(2) class protected by both due process and equal protection clauses).

12. Shutts, 472 U.S. at $811-12$.

13. Prior to $1966, \mathrm{~b}(3)$-type classes were created by putative class members affirmatively opting in. See Frankel, Some Preliminary Observations Concerning Civil Rule 23, 43 F.R.D. 39, 44-46 (1967).

14. Pursuant to the Rules Enabling Act of 1934 the Supreme Court "shall have the power to prescribe ... general rules of practice and procedure of the district courts and courts of appeals ... in civil actions." 28 U.S.C. $\$ 2072$ (1988). In fact, the Rules are written and rewritten by a standing committee-the Advisory Committee-of the Judicial Conference of the United States which forwards its "recommendations" to the Supreme Court and, in turn, to Congress. 28 U.S.C. § 331 (1988); see also, 4 C. WRIGHT \& A. MILLER, FEDERAL PRACTICE AND PROCEDURE $\S 1001$, at 6 (1987). Thus I describe the Rules as statutory.

15. Shutts, 472 U.S. at 811 n.3.

16. Rule 23(c)(2) is limited to actions "maintained under subdivision b(3)." FED. R. CrV. P. 23(c)(2). A court, in its discretion, may order class representatives to afford putative class members the option of leaving the suit. See Holmes v. Continental Can Co., 706 F.2d 1144, 1152-55 (11th Cir. 1983). 
constitutional and prudential admonition that judges should avoid deciding issues not implicated in the immediate case. ${ }^{17}$ The plaintiff class in Shutts was, after all, certified under the Kansas equivalent of 23(b)(3), not $b(1)$ or $b(2)$. Still, one might wonder why, given the Court's failure to identify any limits on the principle implicit in opting out, the Shutts majority went out of its way specifically to cordon off $b(1)$ and $b(2)$ classes. Possibly, the justices foresaw the ultimate reach of an open access principle, and they blinked.

Similarly, the rest of the federal bench does not wholeheartedly support the open access principle in the class action context. Prior to Shutts, lower federal courts had not only refused to recognize unconstrained individualism as a constitutional right, ${ }^{18}$ but they had also affirmatively sought to avoid providing opt out rights by systematically preferring to certify classes under Rule $23 \mathrm{~b}(1)$ or $b(2)$ rather than under $b(3){ }^{19}$

Unconstrained individualism possesses no theoretical or doctrinal monopoly over the class action. Even in the wake of Shutts, there exists latitude to define the theoretical interests at stake in group litigation, and to adjust the requirements for opting out so that the practice better serves those interests.

\section{WHOSE INDIVIDUALISM?}

Although discussing individualism in the class action context most readily calls to mind the plight of the opter out, in fact those litigants satisfied with class membership also hold claim to an individualist interest. The difficulty is that these characterizations of individualism - the unconstrained variety advanced by the opter out and the constrained variety asserted by class members-conflict with one another. As currently written, Rule 23 mistakenly tries to promote unconstrained individualism even in circumstances in which such individualism is unworkable or improper. Before examining the ways in which statutory expression of unconstrained individualism frustrates the ability of class members effectively to vindicate their rights by means of group litigation, and thus is improper, we should observe the ways in which opting out fails to deliver on its promise to protect individual litigants, and thus may be deemed unworkable.

17. See Ashwander v. Tennessee Valley Auth., 297 U.S. 288, 347 (1936) (Brandeis, J., concurring) (Court will not "formulate a rule of constitutional law broader than is required by the precise facts to which it is to be applied") (quoting Liverpool, N.Y. \& Phila. Steamship Co. v. Emigration Comm'rs, 113 U.S. 33,39 (1885)).

18. See supra note 11.

19. See Weiner, The Class Action, the Federal Court and the Upper Class: Is Notice, and its Consequent Cost, Really Necessary?, 22 CAL. WESTERN L. REV. 31, $80-86$ (1985); see, e.g., Stoetzner v. U.S. Steel Corp., 15 Fed. R. Serv. 3d 1325, 1330 (3d Cir. 1990); First Federal of Michigan v. Barrow, 878 F.2d 912, 919-20 (6th Cir. 1989); Reynolds v. National Football League, 584 F.2d 280, 284 (8th Cir. 1978); Robertson v. National Basketball Ass'n, 556 F.2d 682, 685 (2d Cir. 1977); Ste. Marie v. Eastern R.R. Ass'n, 72 F.R.D. 443, 450 n.2 (S.D.N.Y. 1976); Van Gemert v. Boeing Co., 259 F. Supp. 125, 130 (S.D.N.Y. 1966). 


\section{A. Class Members Who Choose to Opt Out: Unconstrained Individualists}

In practice, opting out fails to fulfill the promise of the open access principle supported by unconstrained individualists. As currently formulated, a substantial segment of Rule 23's intended beneficiaries do not enjoy the advantages of the self-exclusion device.

Rule 23's history helps to identify that segment of the class action population to which Rule 23(c)(2) does not speak. Between 1938 and 1966 individuals could only join class suits now categorized as $b(3)$ actions by affirmatively opting in to the suit, thereby voluntarily consenting to be bound. ${ }^{20} \mathrm{~A}$ principal reason for doing away with the opt in mechanism was that, as a practical matter, many who qualified as class members would "for one reason or another, ignorance, timidity, unfamiliarity with business or legal matters, . . . simply not take the affirmative step" of sending to the court a request for class membership. ${ }^{21}$ The dilemma lies in the fact that these "small people,"22 for whom the more coercive opt out procedure was adopted, remain "unfamiliar[] with business or legal matters" long after the 1966 modification of Rule 23. Consequently, one wonders just what the average class member makes of the notice he receives informing him of the pendency of an action and of the opportunity to opt out. . $^{23}$

Speculation about the meaningfulness of class notice, however, is unnecessary. Confusion on the part of class members over the implications of, and methods for, opting out of a class suit is evident in cases in which courts have considered the validity of contested requests for exclusion. ${ }^{24}$ Mashburn $v$. National Healthcare is illustrative in this regard. ${ }^{25}$ There, an Alabama district court allowed the plaintiff class' attorney to contact putative class members who had requested exclusion. That inquiry led the court to conclude that "all of the persons requesting exclusion [that] plaintiffs' counsel have been able to contact did so only by mistake due to the similarity of that form and the proof of claim form." ${ }^{26}$ The limited statistical evidence available suggests that the sort of ignorance among class members uncovered by the Mashburn court, while

20. See Frankel, supra note 13 , at $44-46$.

21. Kaplan, supra note 5, at 397-98.

22. Id.

23. See Kennedy, Class Actions: The Right to Opt Out, 25 ARI. L. Rev. 3, 72 (1983) (many b(3) class members are not large institutional players, and thus have limited litigating experience). For examples of notice and opt out forms, using confusing and intimidating (although accurate) language, see Simmons v. City of Kansas City, No. 88-2603, 1990 WL 58710 (D.C. Kan.) (notice of pendency of action, opt out form, and claim form), and see generally American Bar Association, Antitrust Section of the Civil Practice and Procedure Committee, Manual of Class Action Notice Forms (1979) (notice of pendency of action forms and opt out forms universally using legalistic terms).

24. See, e.g., Valente v. Pepsico, 89 F.R.D. 352 (D. Del. 1981); Perry v. Beneficial Fin. Co., 88 F.R.D. 221 (W.D.N.Y. 1980).

25. 684 F. Supp. 660 (M.D. Ala. 1988).

26. Id. at 667 . 
certainly not present in all class suits, is typical ${ }^{27}$ Moreover, in some instances opters out, typically at the behest of an attorney working on contingency, select exclusion as a bargaining tool against the rest of the class. ${ }^{28}$ No doubt, there are many putative class members who have distinct claims for relief, but are fearful of dilution or prejudice of the strength of their individual claims by aggregation with claims common to the class; these members opt out for valid reasons. However, we should not continue uncritically to sanction often uninformed opting out as an exalted expression of individual liberty. To the extent that we sate our hunger to protect individual rights by this inadequate arrangement, we lack ambition. Promoting unconstrained individualism in group litigation by means of opting out has failed on its own terms-it does not protect meaningful open access.

\section{B. Class Members Who Choose to Remain in the Class: Constrained Individualists}

To the extent that Rule 23 permits opting out on suspect or illegitimate grounds, it frustrates the ability of class members who are satisfied with group litigation - that is, those who wish to be bound by the outcome of the class suit - to obtain legal redress. As currently structured, opting out provides incentives which mute Rule 23's expression of the equal access principle.

Significantly, these incentives did not poison the doctrinal climate when the Advisory Committee revised Rule 23 in 1966. Instead, the Committee largely occupied itself with preventing individual litigants who satisfied the requisites of class membership from intervening after a favorable judgment, thus employing the results of the class suit to further their own interests. Such "post-judgment one way intervention" was criticized for lacking "mutuality"; intervening plaintiffs could benefit from an agreeable judicial decision won by the litigation efforts of the class while at the same time, by virtue of having avoided joining the action as a party, conveniently sidestepping the res judicata implications of a ruling in favor of the defendant. This created disincentives to filing group actions. ${ }^{29}$ The reformers of 1966 hoped to cure this malady by replacing statutory authorization to join a class suit in its latest stages with a rule forcing a choice, either to cast one's lot with the class or to opt out and go it alone, early on in the litigation. ${ }^{30}$

27. Note, The Rule 23(b)(3) Class Action: An Empirical Study, 62 GEO. L.J. 1123, 1149-50 (1974) (finding that many class members were "uneducated, unknowledgeable, or fearful").

28. Coffee, The Regulation of Entrepreneurial Litigation: Balancing Fairness and Efficiency in the Large Class Action, 54 U. CHI. L. REV. 877, 911 (1987) (opting out often used to secure higher contingent fees for attorneys); Weiner, supra, note 19, at $97-99$ (opting out caters to atypical litigants who manipulate the process for exacting undeservedly high awards).

29. Kaplan, supra note 5, at 384-86.

30. Id. 
In 1966, the framers of the Rule had every reason to take the mutuality principle for granted. Subsequent and unanticipated Supreme Court decisions curbing estoppel doctrine's mutuality requirement, ${ }^{31}$ however, "washed away the foundation on which the edifice of Rule 23 had been built." ${ }^{\text {"32 }}$ In the wake of these decisions, most notably Parklane Hosiery Co. v. Shore, a class member can excuse himself from a class suit and wait on the sidelines for a final decision on the merits. Notwithstanding Parklane's admonition to the contrary, if the judgment in the class action is favorable to the class, the self-excluded class member can assert nonmutual offensive collateral estoppel and secure a judgment against the defendant without any effort, expense, or risk. ${ }^{33}$ If, on the other hand, the resolution of the class suit is unfavorable to the class, the individual litigant can bring a separate action, as he would not be bound by the previous suit. ${ }^{34}$

Scholars have noted this free rider problem and its consequent unfairness, both to the members of the class and to their attorneys, who disproportionately bear all of the risks and most of the costs of the litigation. ${ }^{35}$ Given the widely accepted fact that any one person's monetary recovery (where available) is often greater in individual than in group actions, ${ }^{36}$ even good-hearted and civic-minded class members have economic incentives to opt out and allow someone else to bring the suit, waiting to capitalize on risk-free benefits. ${ }^{37}$

31. Parklane Hosiery Co. v. Shore, 439 U.S. 322, 331 (1979) ("preferable approach . . is not to preclude the use of offensive collateral estoppel, but to grant trial courts broad discretion to determine when it should be applied"); Blonder-Tongue Lab v. University of Illinois Found., 402 U.S. 313, 350 (1971) (overruling uncritical acceptance of the principle of mutuality of estoppel).

32. Premier Elec. Const. Co. v. National Elec. Contractors Ass'n, 814 F.2d 358, 362 (7th Cir. 1987).

33. Some courts have acted to curb this practice, using their discretion to deny application of the Parklane doctrine in class suits. Compare Premier Elec., 814 F.2d at 364-67 (adopting "categorical rule" against employment of estoppel by those who opt out of class suits) and cases cited therein and Vas-Cath Inc. v. Mahurkar, No. 88-4997, 1990 WL 125702, 37 (N.D. Ill.) (opter out "is not bound by an adverse judgment in the main action-and correspondingly may not take the benefit of a favorable one") with Saunders v. Naval Air Rework Facility, 608 F.2d 1308, 1312 (9th Cir. 1979) (class member opting out of damages portion of suit may use decision on liability as preclusive); In re Gap Stores Sec. Litig., 79 F.R.D. 283, 305-06 (N.D. Cal. 1978) (limitation on collateral estoppel effect is "beyond the power of the certifying court").

34. See FED. R. CIV. P. 23(c)(2) (class action judgment binds only those who "do not request exclusion").

35. See Kennedy, supra note 23; Ratliff, Offensive Assertion of Collateral Estoppel and the Option Effect, 67 TEX. L. REV. 63 (1988); Weiner, supra note 19; Note, Offensive Collateral Estoppel by Persons Opting Out of a Class Action, 31 HASTINGS L.J. 1189 (1980).

36. Coffee, supra note 28, at 915; Simon, Class Actions-Useful Tool or Engine of Destruction, 55 F.R.D. 375,390 (1973).

37. There is a widespread popular belief that much of the frustration over class action litigation is attributable to attorneys working on a contingency basis. See, e.g., The Bitter Fight Over the Manville Trust, N.Y. Times, July $8,1990, \S 3$, at 1, col. $2 ;$ id. $\$ 3$, at 6 , cols. $4-5$ (partly attributing near bankruptcy of settlement fund in complex asbestos class action to substantial attorneys' fees and attorneys' push to secure higher payments for plaintiffs first in line to collect from the trust). I conflate the role of attorneys and their clients for two reasons. First, the scope of this Note does not permit satisfactory discussion of theoretical, practical, and ethical implications of an attorney's role in a class action suit. Second, I am interested in identifying legitimate independent interests. In an ideal world, attorneys act merely as the agents for opters out or class members, and thus they have no unique interests. That lawyers often seem in fact to act in their own individual interests merely accentuates the destructive economic incentives mentioned in the text. For 
This economic incentive, taken to its logical extreme, would deplete the ranks of class membership to the point where the "numerosity" necessary to maintain a class action in the first place ${ }^{38}$ would simply vanish. In its more realistic and less radical manifestation, the threat to employ the shield of opting out in combination with the sword of nonmutual offensive collateral estoppel allows individual attorneys to exact unearned concessions from the appointed class counsel, essentially creating conflicts within the class where none previously existed. $^{39}$

The corollary to waiting for a judgment is the practice of opting out and "racing to the court." An individual litigant may choose to opt out of the class and seek a judgment against the defendant before, rather than after, the class suit comes to fruition, hoping to reap an enormous personal windfall at the expense of the class. ${ }^{40}$

Both practices prejudice the class. By allowing sophisticated litigants to manipulate the direction and benefits of a class suit these practices impede the ability of class members to invoke the equal access principle. Unconstrained opting out in a post-Parklane world also injures the class in a less obvious way: it reduces opportunities for settlement.

While class members may desire settlement even if some of their number leave the suit, the defendant $t^{41}$ should grow increasingly reluctant to reach agreement with the class as more litigants opt out. Class actions benefit defendants to the extent that they are procedurally fair ${ }^{42}$ and consolidate similar claims held simultaneously by numerous litigants, allowing for convenient disposition of cases. The mutuality requirement's demise, ${ }^{43}$ however, lessened

a comprehensive treatment of this issue, see Coffee, supra note 28 , at 877 .

38. FED. R. CIV. P. 23(a)(1).

39. Davies v. Continental Bank, Nos. 86-6508, 86-7516, 1989 WL 63235 (E.D. Pa. June 9, 1989), presents one such example. There, counsel for opt out plaintiffs requested fees from the settlement fund on the argument that they made settlement possible by "intense[ly]" negotiating between their clients and the rest of the class. The court refused to award the fees because the "conflict created by the opting out [plaintiffs] ... led to what the parties have referred to as intense negotiations." The court reasoned, "Simply because petitioners [sic] representation of their clients was able to be accomplished without the [opters out] releasing a guillotine on the heads of the Class does not mean that their actions provided a 'substantial benefit' to the class members ...."Id. at 9-10; see also, Coffee, supra note 28 , at 911 . This problem is exacerbated when courts consolidate individual suits brought by opters out along with the class action, effectively elevating the bargaining position of the individual litigants relative to the class counsel. See, e.g., A.J. Canfield Co. v. Owens-lllinois, Inc., No. 88-9810, 1989 WL 99756 (N.D. Il. Aug. 23, 1989) (consolidated for pretrail proceedings).

40. Coffee, supra note 28, at 910 . If the individual litigant triumphs, either through settlement or a final decision on the merits, that person may earn so much in actual damages that the defendant will be judgment proof by the time the class action is adjudicated. To reduce such incentives, some commentators have urged adoption of rules denying opters out access to any punitive damages. See id. at 925-30; Putz, Punitive Damage Claims of Class Members Who Opt Out: Should They Survive?, 16 U.S.F. L. REv. 1 (1981).

41. While Rule 23 permits certification of defendant classes, most often plaintiffs seek class status. For this reason, and because plaintiff and defendant classes are treated differently, Shutts, 472 U.S. at 811 n.3, I employ the terms "defendant" and "party opposing the class" interchangeably.

42. Kaplan, supra note 5, at 390 (articulating sensitivity to preserving "procedural safeguards . . . for the opposing party").

43. See supra notes $31-35$ and accompanying text. 
one deterrent to opting out, namely that opters out would face high litigation costs if they were to file individual suits. ${ }^{44}$ Without this deterrent, defendants face two disturbing prospects: higher overall payments and having to defend against more suits.

First, opting out with the prospect of bringing a subsequent individual suit exposes the defendant to multiple judgments, filed virtually cost free by former class members. If we assume that both class suits and individual suits perfectly compensate victims, then this prospect of multiple judgments should not concern us because a defendant will pay out the same aggregate amount under either a regime favoring class actions or one favoring individual suits. For example, in the world of perfect compensation, the defendant should be indifferent between a judgment requiring that she pay $\$ 1,000,000$ to 100 class members and a judgment requiring that she pay $\$ 980,000$ to 98 class members and $\$ 10,000$ each to 2 individual litigants. Recall, however, the litigation dynamic that individual suits yield higher per-person damage awards than class actions. ${ }^{45}$ In practice, the overall cost to the defendant of paying out the resulting awards to opters out can be expected to increase.

Even if the Parklane-created incentives were absent, to the extent that class members leave the class suit, defendants will be hesitant about entering into a settlement with a plaintiff class. Opting out threatens a defendant with numerous suits based on similar, or even identical, factual and legal claims. Defendants, of course, agree to settle in the hope of disposing of claims against them with finality and at a lower cost than a full trial entails. Therefore, each opter out presents the risk of further litigation, or at least of heightened transaction costs in arriving at so many bilateral settlement agreements, exactly the situation which the defendant sought to avoid. ${ }^{46}$

Finally, an increase in suits drains scarce judicial resources. This "secondary goal of judicial efficiency," ${ }^{, 47}$ although only tangentially related to the conflict between the divergent individualist interests involved in the opt out controversy, deserves brief comment. A widely perceived benefit of group litigation is its

44. See Premier Elec. Const. Co. v. National Elec. Contractors Ass'n, 814 F.2d 358, 365-66 (7th Cir. 1987) (but for Parklane doctrine, multiple suits would not arise because of litigating cost to opters out).

45. See supra note 36 and accompanying text.

46. The Seventh Circuit explained,

If defendants anticipate significant opting out, they also will reduce the amounts they offer in settlement, which may in turn make it worthwhile for more parties to opt out. The more attractive it is to opt out ... the fewer settlements there will be, the less the settlements will produce for the class, and the more cases courts must adjudicate. This is not judicial economy at work!

Premier Elec., 814 F.2d at 366. See also Holmes v. Continental Can Co., 706 F.2d 1144, 1153, 1160 (11th Cir. 1983) (allowing opt out privileges in particular b(2) suit although maintaining "general rule" that opting out is to be avoided because of its corrosive effect on settlements); Kincade v. General Tire \& Rubber Co., 635 F.2d 501, 507 (5th Cir. 1981) (refusing to allow opt out privileges in b(2) suit because opting out would "discourage settlements"); In re Four Seasons Sec. Laws Litig., 63 F.R.D. 422, 429 (W.D. Okla. 1974) ("Defendants will be loath to offer substantial sums of money in compromise settlement of class actions unless they can rely on . . . Rule 23 to bind class members.").

47. Frankel, supra note 13 , at 46. 
ability to achieve "economies of time, effort, and expense" 48 by combining similar claims into a single suit. ${ }^{49}$ While procedures that reduce settlement opportunities are inconsistent with judicial preference for settlement, ${ }^{50}$ we should not take this argument too far. The greatest cost savings would accrue to a court that simply refused to recognize any group litigation, assuming that erstwhile class members with small claims would not access the courts at all in the absence of the class device. ${ }^{11}$ Fortunately, however, courts exist first and foremost to define rights and duties and to fashion remedies for wrongs; therefore, minimizing costs must always remain a secondary goal.

The failure of unconstrained individualism, as embodied in Rule 23's opt out provision, to protect the rights of legally unsophisticated class members, its frustration of the equal access ideal on which the class action is fundamentally predicated, and the added administrative expense that it generates, pose a challenge: can we recast opting out such that it lives up to our varied aspirations for group litigation without unduly compromising important individual rights cherished in and inscribed upon the American legal system?

\section{A GoOd CAUSE Showing PrIOR to OPTING OUT}

One way to begin recasting the class action is by purging it of excessive deference to unconstrained individualism. While no one doubts that control over one's own litigative destiny is a deeply valued right, an open access principle is, by and large, inappropriate in the class action context.

To appropriately confine the open access principle of group litigation, this Note proposes adding a good cause requirement to Rule 23(c)(2). Such a requirement would limit a class member's ability to opt out of a class suit to those instances in which he could demonstrate that the class will not adequately

48. Amendments to the Rules of Civil Procedure, supra note 2, at 102-03.

49. See Shutts, 472 U.S. at 814 (rejecting argument that due process requires opt in procedure in favor of "the obvious advantages in judicial efficiency resulting from the "opt out' approach"); Guthrie v. Evans, 815 F.2d 626, 629 (11th Cir. 1987) ("A fundamental purpose of the class action is to render manageable litigation that involves numerous members of a homogenous class, who would all otherwise have access to the court through individual lawsuits."); 7A C. WRIGHT, A. MILLER \& M. KANE, FEDERAL PRACTICE AND PROCEDURE § 1751, at 8 (1986). But see Guthrie, 815 F.2d at 628 (opting out allows those dissatisfied with the class device early exit, thus reducing appeals). Also, given the right to intervene through counsel provided for in Rule $23(\mathrm{c})(2)(\mathrm{C})$, whether a class suit featuring many attorneys representing many more concerned class members would actually prove less of a drain on judicial resources than a number of more harmonious although discrete suits brought simultaneously is at least a fair question.

50. Settlement is widely recognized as an efficient method of dispute resolution, both because much of the work is done by the parties, who know their interests better than a court, and because the pendency of the action is of shorter duration than it would be if the case went to trial. Mashburn v. National Healthcare, 684 F. Supp. 660,669 (M.D. Ala. 1988) ("The law is clear that early settlements are to be encouraged."); In re Four Seasons Sec. Laws Litig., 63 F.R.D. at 429 ("It has long been recognized that the courts favor the settlement of controversies.").

51. See Shutts, 472 U.S. at 812-13 (class actions only practical and economical way for aggrieved parties to bring smaller claims); Simon, supra note 36, at 377 (complaining that Rule 23(b)(3) transmogrifies federal judiciary "into a small claims court"). 
represent his interests. ${ }^{52}$ This showing would require each opter out to demonstrate that he is alleging some unique substantive legal issue or material fact, or a unique way of presenting a substantive legal issue or material fact, that the class suit will not fully and fairly address. The standard would allow opting out if, for instance, a plaintiff alleging fraud argues that a different set of facts led him to rely detrimentally on representations made by the defendant, or that his position as a corporate employee established a legal relationship between himself and the defendant distinguishable from that which obtained between the defendant and the rest of the class. On the other hand, an individual would not satisfy the heightened standard for exclusion if he were merely to claim that he had been aggrieved to a greater financial extent than most or all of the members of the class. The standard comprehends differences in kind but is blind to differences in degree.

The definition of "good cause" under the proposed test is left vague, to be filled in by courts with a view to ensuring that class members' interests are adequately represented..$^{53}$ This vagueness should not be troubling. Other sections of the Federal Rules incorporate good cause requirements. ${ }^{54}$ Additionally, an overly specific description of the proposed rule would be too rigid to stand the test of time. ${ }^{55}$ Such flexibility is the advantage of the common law method, which draws upon the lessons of experience to mediate between sterile rules and the living facts of a particular case. Moreover, although the determination of whether factual issues or legal claims are substantially different might be difficult at times, courts already routinely make such judgments, both during the pendency of class actions, ${ }^{56}$ and subsequent to them. ${ }^{57}$

52. Accordingly, Rule 23(c)(2) might read: "In any class action maintained under subdivision (b)(3), the court shall direct to the members of the class the best notice practicable under the circumstances, including individual notice to all members who can be identified through reasonable effort. The notice shall advise each member that $(A)$ the court will exclude the member from the class if the member shows good cause by a specified date; (B) the judgment, whether favorable or not, will include all members who do not show good cause for exclusion; and (C) any member who does not show good cause for exclusion may, if the member desires, enter an appearance through counsel."

53. Rule 23 already requires that named plaintiffs adequately represent the class. See supra note 2. The good cause standard complements this requirement by identifying the representational concern as central to the open access principle, and thus it attempts to define the limits of open access in the class action context.

54. See, e.g., FED. R. CIV. P. 6(b) (allowing time extensions "for cause shown"); FED. R. CIV. P. 30(b)(3) (modification of time for taking of deposition "for cause shown"); FED. R. CTV. P. 35(a) (court may order physical or medical examination only "for good cause shown"); FED. R. CIV. P. 55(c) (court may set aside default judgment "for good cause shown").

55. Compare Amendments to the Rules of Civil Procedure, supra note 2, at 103 (prediction that 23(b)(3) class actions were "not appropriate" in mass tort cases) with Ratliff, supra note 35, at 65-68 (recent developments favor use of mass tort class actions) and Note, Was the 1966 Advisory Committee Right?: Suggested Revisions of Rule 23 to Allow More Frequent Use of Class Actions in Mass Tort Litigation, 25 HARV. J. ON LEGIS. 461 (1988) and Rosenberg, Class Actions for Mass Torts: Doing Individual Justice by Collective Means, 62 IND. L.J. 561 (1987).

56. See, e.g., Davis Enters., Ltd. v. EPA, No. 87-5315, 1988 WL 91123, 4 (E.D. Pa. Aug. 30, 1988) (individual suits filed by opters out are "similar to" the class action); Holland v. United States, No. 88-468, 1988 WL 71941, 2 (D.D.C. June 27, 1988) (claims raised by b(2) class members "are identical to those raised" in class action). 
Even setting implementation problems aside, the good cause requirement bears a heavy burden if it is to justify revision of the Federal Rules. The modified rule must both sufficiently accommodate legitimately asserted open access rights and, at the same time, weed out illegitimate manifestations of the open access principle so as effectively to promote group litigation's equal access ideal.

Unquestionably, the good cause requirement impinges to some undefined extent on the open access principle in that it makes leaving a suit more difficult than under the current statutory regime. However, several reasons suggest that such a consequence should not be alarming. After all, limiting individual control of a lawsuit does not completely eliminate such control. Important open access rights, such as ensuring that one's factual situation and "theory of the case" are heard in court, are preserved by the availability of systemic correctives which allow the expression of individuality within the confines of the class structure. Among these are the statutorily furnished opportunity to intervene through counsel, ${ }^{58}$ and the possibility of court ordered subclassing on particular issues, such as damages. ${ }^{59}$ More fundamentally, the good cause requirement still allows putative class members with distinct claims to leave the suit. The modified Rule denies self-exclusion only to class members with claims indistinguishable from those held by the class representatives. The modified Rule thus relies on and imposes a normative judgment about the legitimate circumstances in which opting out should be allowed. Note that Rule 23 already makes just this sort of judgment in denying opt out rights across the board in $b(1)$ and $b(2)$

57. See, e.g., Robinson v. Long Island R.R., No. 85-456, 1989 WL 140593, 3-4 (E.D.N.Y. Nov. 15, 1989) (because b(2) class member could not "pursue a separate action that involves the same subject matter against the same defendant" both during and after resolution of the class suit, "the courts have consistently barred Capers class members from pursuing separate actions against the LIRR for racially motivated employment discrimination"); DiLeo v. Baumhart, No. 84-7305, 1989 WL 39784, 2 (dismissing subsequent class action brought by opters out of first class action on grounds that second suit was based on "same factual scenario").

58. FED. R. CV. P. 23(c)(2)(C) ("any member . . . may . . . enter an appearance through counsel"); see Guthrie v. Evans, 815 F.2d 626, 628 (11th Cir. 1987) (refusing to hear appeal of unnamed class member because he had not availed himself of intervention as "a means whereby class members can monitor the representation of their rights"); Hoston v. United States Gypsum Co., 67 F.R.D. 650, 658 (E.D. La. 1975) (notice in $b(2)$ action must inform class members of their right to intervene under Rule 23(d)(2)). But see DeGier v. McDonald's Corp., 76 F.R.D. 125, 127 n.1 (N.D. Cal. 1977) ('intervention still requires an absent plaintiff class members [sic] to involve themselves in a law suit not of their own choosing").

59. See Premier Elec. Const. Co. v. National Elec. Contractors Ass'n, 814 F.2d 358, 366 (7th Cir. 1987) ("Different members of the class may suffer different kinds of damages, but this is a reason to establish subclasses ... rather than to increase the number of separate suits."); Holmes v. Continental Can Co., 706 F.2d 1144, 1158 (11th Cir. 1983) ("[B]ifurcated procedure reflects a sensitivity toward the heterogeneous quality of the claims resolved at the monetary relief stage."); Officers For Justice v. Civil Serv. Comm'n, 688 F.2d 615, 634 (9th Cir. 1982) (bifurcating trials into separate liability and damages phases and tailoring class certification appropriately); Supermarkets Gen. Corp. v. Grinnell Corp., 490 F.2d 1183, 1184 (2d Cir. 1974) (defining class for settlement purposes only); Mashbum v. National Healthcare, 684 F. Supp. 660, 665 n.4 (M.D. Ala. 1988) (citing cases allowing bifurcated proceedings); Frankel, supra note 13, at 47 (urging bifurcated trials). 
actions. ${ }^{60}$ Similarly, preclusion doctrines place off limits certain rationales that a litigant might offer in support of a claim. Res judicata and collateral estoppel impose constraints on a litigant's freedom to argue in her own behalf when the substance of that argument has already been heard. ${ }^{61}$

Important individual interests are not threatened even in those situations in which a class member has a distinct claim but finds the good cause standard difficult to satisfy. To understand the practical effects of the good cause requirement, two types of putative class members legitimately seeking to exit a class suit-the legally sophisticated and the legally unsophisticated-must be distinguished from each other. We have seen that litigants without access to legal counsel, those litigants termed legally unsophisticated, opt out only rarely and, when they do opt out, they quite possibly act in ignorance of the consequences of their choice. ${ }^{62}$ Thus, for this group, the current regime fails to ensure meaningful control over one's own litigation largely to the same extent as would the good cause requirement. Under both the current and the reformed rule these litigants would most likely not take the appropriate steps necessary to perfect an individual claim.

Some class members with access to counsel and experience in the courts, those termed legally sophisticated, also might well desire exclusion for legitimate reasons and wish independently to arrive at decisions about when and whom to sue. While anyone could appear before a court to show good cause pro se, the gravity of the situation will in most instances require serious litigants to obtain the assistance of counsel for the good cause hearing. ${ }^{63}$ The disadvantage of the good cause requirement seems to be that it imposes a novel financial burden on class members legitimately requesting exclusion. The Supreme Court, in Shutts, observed a simple but subtle practical reality that renders this concern with cost insignificant: "If . . . the plaintiff's claim is sufficiently large or important that he wishes to litigate it on his own, he will

60. Rule 23(d)(2), which is a "general statement of the equitable powers" of a federal district judge presiding over a class action suit, 7B C. WRIGHT, A. MILLER \& M. KANE, supra note 2, § 1793, at 294 (1986), arguably vests standardless discretion to allow opting out to $\mathrm{b}(1)$ and $\mathrm{b}(2)$ class members, $i d . \S 1793$, at 311 ("court may send notice authorizing class members to opt-out in a Rule 23(b)(2) action"). Most often, however, courts refuse to permit opting out of $b(1)$ and $b(2)$ classes. See, e.g., Nottingham Partners v. TransLux Corp., No. 88-0591, 1990 WL 93513, 3 (D. Mass. June 27, 1990) (denying (b)(2) class members opt out privilege); Bandala v. Armstrong-Blum Mfg. Co., No. 87-5923, 1988 WL 2771, 3-4 (N.D. Ill. Jan. 12, 1988) (same). Resistance to allowing opting out except where absolutely necessary is also reflected in district courts' systematic preference for certifying classes pursuant to $b(1)$ and $b(2)$ rather than to $b(3)$, see supra note 19.

61. F. JAMES \& G. HAZARD, CIVIL PROCEDURE § 11.2 (1985) (Preclusion "give[s] recognition to the fact that the purpose of a lawsuit is not only to do substantial justice but to bring an end to controversy. This is true ... . so that the moral force of court judgments will not be undermined."); 18 C. WRIGHT, A. MILLER \& E. COOPER, FEDERAL PRACTICE AND PROCEDURE $\S 4403$ (positing varied justifications in favor of preclusion rules).

62. See supra notes 19-26 and accompanying text.

63. See In re Four Seasons Sec. Laws Litig., 493 F.2d 1288, 1288-89 (10th Cir. 1974) (selecting "reasonable indication of a desire to opt out" standard because "it certainly would be an undue burden on class members to require them to retain counsel and prepare a formal legal document"). 
likely have retained an attorney or have thought about filing suit." 64 Only litigants already prepared to bear the cost of an attorney for the prosecution of a separate action will incur the margin of additional cost generated by the good cause showing.

Having demonstrated that the good cause requirement frustrates the open access principle only minimally, it is important to understand how the good cause requirement affirmatively promotes the equal access principle. By transforming opting out into a representational device, the reformed rule benefits the impoverished, ignorant, ${ }^{65}$ or absent ${ }^{66}$ litigant with a valid individual claim, but who has difficulty asserting his distinct interest. Litigants who, with the aid of counsel, do elect to come forward and opt out will stand as representatives for those who cannot enlist legal assistance and are incapable pro se. Properly treated, opters out making the good cause showing will make "helpful suggestion[s]" about the definition of the class itself. ${ }^{67}$ If cause is shown the court could choose either to define a subclass with respect to certain issues or simply to hold that the trial court should never have included litigants of certain types in the class in the first place. ${ }^{68}$ Opting out becomes a judicial ocular, which a judge may use to penetrate the opacity of class composition. As such, it promotes a central concern of individualism, namely equal court access for vindication of legal rights.

Additionally, the good cause requirement supports the equal access principle by reducing incentives for strategic opting out and filing of multiple suits turning on identical issues. If all who share the same claim must litigate it at the same time in the same action, there can be no racing to the court against the class. Nor can there be any sideline sitting. If the certifying court defines the class with sufficient accuracy and scope, all those putative class members

64. Shutts, 472 U.S. at 813 (emphasis added). The Court went on to observe that the opt out provision should not be tailored to "the somewhat rare species of class member" holding an independently justiciable claim but who is "unwilling to execute an 'opt out' form." Id. at 813-14. Although the Court in Shutts was explaining why an opt out procedure need not be replaced by an opt in procedure, once the central observation-that many class members with substantial, individually discrete claims will have already retained counsel-is accepted, the logic applies with equal force to the "rara avis" who does not choose representation by counsel at the good cause hearing. See also Coffee, supra note 28 , at $904-06$ (only those with "independently marketable" claims will opt out).

65. See supra notes 19-26 and accompanying text.

66. Even in $b(3)$ suits, in which individual notice is required, not all class members actually receive notice. See Mullane v. Central Hanover Bank \& Trust Co., 339 U.S. 306, 317 (1950) ("II]n the case of persons missing or unknown, employment of an indirect and even a probably futile means of notification ... creates no constitutional bar to a final decree foreclosing their rights.") (decided before 1966 amendments); Note, The Rule 23(b)(3) Class Action: An Empirical Study, supra note 27, at 1146 (individual notice sent by class representatives is not actually received by some class members).

67. Mashburn v. National Heaithcare, 684 F. Supp. 660, 672 (M.D. Ala. 1988). The Mashburn court used objections raised by some class members at a settlement conference as indicia of objections which might be raised by other absent class members. Id. at 679 .

68. Id. at 673; see also Kaplan, supra note 5, at 396 (courts should consider dissenters who intervene under Rule 23(c)(2)(C) representatives of absent class members); Note, The Rule 23(b)(3) Class Action: An Empirical Study, supra note 27, at 1141 (at commencement of class suit attorneys define class in vague terms, a problem made more acute by ethical canons proscribing solicitation of clients). 
sitting out the suit will by defintion be allowed to assert issues of law or fact distinct from those being adjudged in the class action; they can take nothing of value from even the most favorable resolution of the class suit. Similarly, because class members have no incentive to opt out and then wait on the sidelines, defendants need not fear the initiation of hundreds or thousands of duplicative, independent suits and the subsequent stream of payments implied by the Parklane doctrine. Additionally, the absolute number of suits actually filed on the same legal and factual issues will decline, as the opt out provision consolidates substantially similar claims. This is so because, having greater certainty about the total amount of damages and the fact that there will be fewer suits, defendants should have increased confidence in the efficacy of settlement. To the extent that the good cause requirement reduces the incentives for destructive intraclass or class/individual rivalry, it promotes the equal access principle for class members who choose to remain in the suit, as it ensures that they will have "their own day in court."

Having a day in court means that justiciable claims will be given a timely and complete hearing in a competent forum, not perfunctory dismissal demanded by scarce judicial resources. More settlements and fewer filings free courts from the expense of hearing duplicative litigation. Judges may consequently devote more attention to discrete substantive claims. In this attenuated way, court frugality is encouraged not for its own sake, but as an instrumental good, making court access for valid claims not only available, but also meaningful. Objectors will point to the irony of claiming to reduce costs through the creation of another hearing procedure, a reform that seems, on its face, to consume more judicial resources than an unregulated, wholly elective opt out mechanism. However, the conservation of judicial resources through the abolition of duplicative litigation, from filing through discovery and trial, may easily be expected to outweigh the cost of even a great many exclusion hearings. ${ }^{6}$

Once the role of unconstrained individualism in the class action context is properly confined to those instances in which the opter out holds a claim

69. Three other points support the cost-saving argument. First, the current opt out procedure, which is ostensibly simple and thus encourages pro se filing, is not completely free of administrative costs. See, e.g., Valente v. Pepsico, 89 F.R.D. 352 (D. Del. 1981) (considering validity of misfiled opt out and claim forms); Perry v. Beneficial Fin. Co. 88 F.R.D. 221 (W.D.N.Y. 1980) (considering validity of opt out requests filed by class members acting pro se). Second, creating a new procedure to save resources over the long term is a well accepted practice. One such example is the argument persuasively used by the Supreme Court in Parklane to relax the mutuality-of-estoppel doctrine. There, the Court established the functional equivalent of a good cause showing that would have to be applied in each case, but that over time was likely to reduce the enormous costs associated with duplicative trials. Parklane Hosiery v. Shore, 439 U.S. 322, 331-33 (1979). Third, one would expect the costs associated with a good cause showing to decrease over time in absolute terms since future litigants will draw on common law interpretations of the Rule's language to govern their conduct. The litigation cost curve will be steepest just after the good cause requirement is adopted. Of course, similar costs in testing the limits of this new rule could be expected to accompany any rule change whatsoever, simply because it is a new presence on the legal landscape which both judges and litigants must assimilate. 
distinct from that of the class representative, the Federal Rules should tolerate opting out for cause in $b(1)$ and $b(2)$ actions. Recall that currently the Federal Rules presuppose that in $b(1)$ and $b(2)$ classes any one class member will adequately represent another because their interests are the same. They form a "cohesive" class and therefore the Rules deny any opportunity to leave a class suit. ${ }^{70}$ The project of this Note, although principally examining $b(3)$ suits, has been to question just that sort of presumption. Similar analysis should, and does, apply to $b(1)$ and $b(2)$ classes. Concededly, if cohesiveness means that the interests of all $b(1)$ and $b(2)$ class members are identical, then there is no practical reason to afford them opt out privileges; opting out in such cases simply encourages relitigation of the same issues. Surely, however, all $b(1)$ and $b(2)$ class litigants cannot possess identical claims in the strongest sense of the word. One justification for the very existence of $b(1)$ and $b(2)$ class suits is that those plaintiffs might independently pursue at least nominally different, and possibly inconsistent, claims and remedies. ${ }^{71}$ Consolidation into a class action is possible and desirable because the claims are more similar than different, but they are not necessarily identical. ${ }^{72}$ Affording $b(1)$ and $b(2)$ class members the chance to opt out would allow them to advance these often important, ${ }^{73}$ distinct claims. ${ }^{74}$

An additional fear assuaged by the denial of opt out privileges in both $b(1)$ and $b(2)$ actions is that multiple suits will yield "inconsistent standards of conduct for the party opposing the class." 75 This certainly militates against

70. See Mullane, 339 U.S. at 319-20 ("The individual interest does not stand alone but is identical with that of a class.... Therefore notice reasonably certain to reach most of those interested in objecting is likely to safeguard the interests of all."); see also supra note 5 and accompanying text.

71. See supra note 2 .

72. This similarity component is most easily seen in the $b(3)$ requirement that claims of the class "predominate" over individual claims. Even in $b(1)$ and $b(2)$ suits, the prerequisite is that questions of law or fact be "common" to the class and that the claims of the named class plaintiffs be "typical" of those of the class as a whole. The language of $b(1)$ and $b(2)$ is couched in terms such as "grounds generally applicable to the class" and nowhere mentions the more rigorous requirement that factual situations and legal claims of all class members be identical. See, e.g., Vargas v. Calabrese, 634 F. Supp. 910, 918-19 (D.N.J. 1986) ("This prerequisite [commonality] requires only that there be some questions of law or fact common to the class. It is not necessary that all the factual or legal issues raised by the case concern each class member." (emphasis in original)).

73. See Schuwerk, Future Class Actions, 39 BAYLOR L. REV. 63, 134-35 (1987) (questioning wisdom of system which lends greater protection to property interests than to liberty interests often implicated in $b(1)$ and $b(2)$ suits).

74. One might be tempted to resolve this difficulty by observing that a plaintiff with a distinct claim would not be precluded in a future action subsequent to the class litigation because preclusion only applies where the claims are identical. The rules of merger and bar, however, dictate that a plaintiff must present every issue supportive of her claim in a single action or not raise them at all. See RESTATEMENT (SECOND) OF JUDGMENTS $\S \S 18,19,24$ (1982). If the class loses on a particular claim for failure to raise certain issues, the harm to the individual plaintiff who would have raised those issues is obvious. Even when the class wins, however, if relief is not adequate for an individual class member, she could find herself barred from initiating a second case to perfect that relief. Precise definitions of "claims" and "issues" are elusive and the subject of much controversy. 18 C. WRIGHT, A. MLLER \& E. COOPER, supra note 2, at $\$ \$ 4402-4403$, 4406-4407. This indeterminacy might encourage a putative class member, whose nominally independent claim might be precluded in future litigation, legitimately to seek exclusion.

75. FED. R. CIV. P. 23(b)(1)(A). 
unregulated opting out, where two or more litigants might present exactly the same claim in independent actions. But, as we have seen dramatically in the $\mathrm{b}(3)$ context, the solution to this problem is regulation-constraint-not prohibition. Application of a good cause test will place off-limits certain parasitic and destructive reasons for a litigant's conduct. At the same time, an individual legitimately petitioning for exclusion will serve not only her own interests; she will also inform the court that a judge's initial certification of the class may have been overbroad or unsophisticated, and thus will help make meaningful the important individual rights our system most assiduously endeavors to support.

\section{CONCLUSION: THE INDIVIDUALIST LEGACY AND GROUP LITIGATION}

To say that opting out protects individual rights against tyrannical group litigation practices grossly oversimplifies the complex interests involved in the modern class action. Properly characterized, individualist concerns pervade the class suit and are experienced in different but important ways by both opters out and those people satisfied with class membership.

Putative class members have no legitimate interest in pursuing the practice of unregulated opting out. The reformulated opt out rule proposed in this Note more closely ties the seemingly anomalous opt out provision currently in force to the equal access principle at the core of group litigation. The good cause requirement does not impinge upon individual rights so much as it defines the scope of competing individualist ideals within the class action context. Conceptualized in this way, individualism and group litigation need not be locked in a continual battle for supremacy; rather, they are mutually vital components of a system which seeks to vindicate rights contemporaneously enjoyed by many. 
